ROBERTO CANOVAI ${ }^{\mathrm{a}}$ - AUGUSTO LONI ${ }^{\mathrm{a}}$

\title{
LADYBIRD COMMUNITIES STRUCTURE IN THREE ITALIAN VINEYARDS
}

\author{
${ }^{a}$ Dept. of Agriculture, Food and Environment, University of Pisa, Via del Borghetto, 80, 56124 Pisa Italy 1. \\ Corresponding Author:Augusto Loni; augusto.loni@unipi.it
}

Canovai R., Loni A. - Ladybird communities structure in three central Italian vineyards.

The knowledge of arthropods communities, their ecological structure and relationships are crucial for a correct management of agroecosystems, particularly in Integrated Pest Management (IPM) and Organic Management. The coccinellid community structure of three differently managed vineyards, two organic and one conventional, has been studied for two consecutive years. Ladybirds were sampled by using Malaise traps. Specimens collected were classified at species level. The Ladybirds communities structure has been analyzed at compositional and functional levels. The results obtained showed the presence of a high number of species all over the three vineyards (40 species in 2012 and 38 in 2013). Aphidophagous represented the main trophic guild. The communities of the three vineyards resulted well separated by the compositional and functional biodiversity analysis. The vineyards with herbaceous cover plants sustained a significant higher population of ladybirds than vineyards with a reduced herbaceous cover. Chemicals treatments produced a significant decreasing of coccinellid populations in the conventional vineyard. The study showed that a rich and diversified coccinellids population enhances the resilience of the agroecosystem vineyard, where the lost or reduction of a species was compensated with the arrival or a growth of other species.

KEY WorDS: Coccinellidae; trophic guilds; resilience; biodiversity; Malaise.

\section{INTRODUCTION}

The intensification of agricultural practices produces loss of habitats, landscape simplification and biodiversity reduction. An extended knowledge of the arthropod communities and their ecological structure in the agroecosystems is crucial to reduce the use of chemicals with the perspective to adopt strategies based on Integrated Pest Management (IPM) or Organic Management. Vineyard is one of the most economically important agroecosystems in the Mediterranean basin and represents a permanent crop that allows the development of well- established insect communities.

Previous studies on the vineyard arthropod fauna were mainly focused on the pest component, with about 150 species classified as noxious (BENTLEY et al., 2005), and on their specific predators or parasitoids (ALTIERI et al., 1993; MENALLED et al., 1999), but scarce are the information regarding the general biodiversity (VINCENT et al., 2012). Research carried out in the last decade, focused on the vineyard arthropodofauna in Canada, produced data about cicadellids (BOSTONIAN et al., 2003), carabids (GOULET et al., 2004), spiders (Bolduc et al., 2005), curculionids (BOUCHARD et al., 2005), chrysomelids (LESAGE et al., 2008) and coccinellids (LuCAs et al., 2007). The results of all these papers converged in outlining the potentiality of the ecological structure of the vineyard in hosting a high level of biodiversity (VINCENT et al., 2012). Ladybirds (Coleoptera: Coccinellidae) include major predators of harmful arthropods in agriculture and play an important role in reducing populations of many small insect pests such as scale insects, mealy bugs, aphids, psyllids, whiteflies, jassids and mites (CODERRE, 1988; Wise et al., 1995; SHANTIBALA et al., 1997; JosHI et al., 2012; Ali et al., 2014).

Coccinellids occur in any terrestrial ecosystem and agroecosystem, resulting very able to colonize various habitats, but showing strong sensitiveness to pesticide use in agricultural practice (ZAHOOR et al., 2003).

Many studies underlined as such group of predators would take advantage by the presence of a rich, wild vegetation surrounding the crops. It can offer shelters, alternative food resources as well as the possibility to perform spillover from the crops to the surrounding areas in case of human perturbations or treatments (RoOT, 1975; LANDIS, 1994; Altieri, 1999; Nichols et al., 2000, 2001, 2008; Thomson \& Hoffman, 2009). For these reasons, coccinellids represent good bioindicators, producing useful information on the habitats where they live (ANDERSEN, 1999; IPERTI, 1999; HEMCHANDRA et al., 2010).

More than $90 \%$ of coccinellids are predators (IPERTI, 1999), feeding on a wide range of insect orders (OBRYCKI et al., 2009; Evans, 2009; HodEK \& HoNĚK, 2009) as well as on mites (BIDDINGER et al., 2009). By considering the totality of the world coccinellid population, their main food resource are the coccid scale insects and mealybugs, preyed by $36 \%$ of all the coccinellid species, followed by aphids $(20 \%)$; on the contrary, in the regions characterized by coldtemperate climes, the rate completely changes and aphids represent the main resource, exploited by $68 \%$ of coccinellids species (HODEK \& HONĔK, 2009). Most of vineyards fall in these climatic areas and host populations of both these pests.

The knowledge of the coccinellidofauna of the Italian vineyards is scarce and only in the recent years contributions to this topic were produced (CANOVAI et al., 2014; Loni et al., 2014; SommagGio \& Burgio, 2014; Burgio et al., 2016; LAMI et al., 2016).

In this paper we investigated for two consecutive years the coccinellid communities in three vineyards of Tuscany. The aim of this research was to evaluate how different management systems can influence the population of coccinellids occurring in such agroecosystem. In particular, 
we focused on the effect of vegetation structure of the three vineyards and on the coccinellids compositional and functional biodiversity associated with it by analyzing: a) the structure of the community at the species level; b) the potentiality to discriminate different vineyards on the base of the community structure of the coccinellids; c) the species richness of each environment; d) the vegetal habitat variables that contributed in determining the community structure of the coccinellids.

\section{MATERIALS AND METHODS}

\section{EXPERIMENTAL AREA}

Surveys were carried out in 2012 and 2013 in three vineyards (labelled as $\mathrm{Md}, \mathrm{O}$ and $\mathrm{C}$ ) in the Province of Pisa, District of Crespina. The three vineyards extended for 40 , 30 and 2 hectars respectively and developed between 15 and 50 meters above sea level. All the experimental units were included in an area of 3 kilometers of diameter consenting to reduce variation of topographical and weather conditions, though their borderlines remain away to each other of at least 1 kilometer. The sites of the observations have these coordinates: $\mathrm{Md}\left(43^{\circ} 59^{\prime} 43^{\prime \prime} \mathrm{N}, 10^{\circ} 57^{\prime} 25^{\prime \prime} \mathrm{E}\right), \mathrm{O}\left(43^{\circ} 58^{\prime} 49^{\prime \prime} \mathrm{N}\right.$,

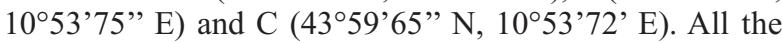
vineyards resulted homogeneous as regards the average age of the plants (ranging between 8 and 10 years) and adopted their specific management systems by at least 5 years. That allowed operating in an ecological structure with an established insect community, well integrated with the study environment. The three vineyards adopted different management strategies to control the main pest Lobesia botrana (Denis \& Schiffermüller) (Lepidoptera, Tortricidae). Vineyard $\mathrm{Md}$ is an organic vineyard adopting the mating disruption technique (MD), $\mathrm{O}$ is an organic farm not using any chemicals and $\mathrm{C}$ is conventional, where Chlorpyrifos was sprayed once or twice a year. As regards the soil management, during the spring and summer periods, Md adopted an alternate tillage within the rows, maintaining an herbs cover on the no tillage row, whereas $\mathrm{O}$ and $\mathrm{C}$ were tilled within all the rows to reduce water traspiration from the soil. Rows with herbs cover of $\mathrm{Md}$ vineyard, were periodically cutted to make easier the access onto the vineyard.

\section{INSECT SAMPLING METHODS}

Insects were sampled by using two Malaise traps in each vineyard. They were set up approximately in the center and near the edge of the studied plots, maintaining a distance of about 60 meters between both traps. Such positioning allowed obtaining a more complete sampling of the entomofauna graviting in the experimental area (FRASER et al., 2007, 2008; LONI \& LUCCHI, 2014). Malaise continuously worked from the half of May to the beginning of October, both in 2012 and 2013 (17/05-20/09/2012 and 16/05-8/10/2013). Trap containers have been changed biweekly.

\section{LocAl Vegetation Assessment}

To describe the vegetation and the habitat sources we delimited a circular transect (50-meter ray) around each trap and scored all the trees (woody species higher than 3 meters) and the number of the wild, woody shrub species. During the same dates of the samples collection, we estimated the surface covered by herbs by throwing randomly a square grid of $20 \mathrm{~cm}$ of side and by evaluating the herbs covering inside it. We performed thirty throws in each trap site, visually choosing the zones with macroscopically different herbs occurrence. We extended the average cover percentage to the entire experimental area, obtaining the herbs cover relative to each date. Trees, shrubs and herbs represent the main structural vegetation components, adopted as habitat indicators in determining arthropods abundance and diversity (FRASER et al., 2007).

\section{COCCINELLIDS DETERMINATION}

We separated coccinellids from the other specimens and stored them under alchool solution ( $70 \%$ volume). Classification at the species level was carried out, basing on morphological features and, if needed, by the genitalia analysis, according to the descriptions of PORTA (1929), FÜRSCH et al., (1967), GOURREAU (1974), CANEPARI (1983 and 2000), CANEPARI \& TEDESCHI (1977) and CANEPARI et al. (1985). Information regarding the food preferences of coccinellids were given by SAHAROUI (1994), IPERTI (1999), Gerson et al. (1975), IABLOKOF-KHNZORIAN (1982), Majerus (1994), Klausnitzer \& Klausnitzer (1997), SAHAROUI \& GoURREAU (1998), Kontodimas et al. (2007), HODEK \& HonĔK (2009). The community structure of coccinellids of the three vineyards was analyzed on the base of their species compositional biodiversity and also by grouping them on the base of the trophic guild they belong (Saharoui,1994 modified). Six trophic guilds were selected: predators of aphids (Aphidophagous $=$ Ap), of coccids (Coccidophagous $=\mathrm{Co}$ ), of mites (Acarophagous $=\mathrm{Ac}$ ), of aleyrodids (Aleurodophagous $=\mathrm{Al}$ ), mycophagous coccinellids (Mycophagous $=\mathrm{My}$ ) and others $(\mathrm{O})$, the last one considering all the species that can prey either on aphids or coccids as well as species whose diet is not well defined. The nomenclature adopted is that proposed by CANEPARI (2013). The coccinellid classifications usually adopted, were proposed by SASAJ (1968) and KovAR (1996). ŚLIPIŃSKI (2007) found these classifications artificial and phylogenetically unacceptable and proposed the splitting of Coccinellidae into two subfamilies: Microweiseinae and Coccinellinae. Afterwards ŚLIPIŃSKI \& TOMASZEWSKA (2010) and SEAGO et al. (2011) formalized the separation of Coccinellidae into the two subfamilies, with Coccinellinae containing most of the tribes. We followed the taxonomy proposed by ŚLIPIŃSKI (2007) and SEAGO et al. (2011).

\section{STATISTICAL ANALYSis}

Total abundance of ladybird populations in both the years, among the three vineyards, has been confronted by Chi square test, adopting a $\mathrm{p}<0,001$ value, by using an interactive calculation tool for chi-square tests of goodness of fit and independence (PREACHER, 2001).

We organized all the sampled specimens in two raw data matrices. In the first, we arranged an array of rows containing all the species and columns with all the Malaise trap samples. In the second one, we grouped the species on the base of their trophic guilds. A $\log (\mathrm{X}+1)$ transformation of the raw data was applied to avoid the right-skewed distribution of the species. On the transformed data matrix, we calculated the Bray-Curtis similarity coefficient to obtain a similarity matrix reporting the similarity percentage values among all the couples of samples. We performed an ordination technique as the non-metric multidimensional scaling (NMDS), producing a configuration in two dimensions of the coccinellid species samples.

To visualize differences or similarities among the coccinellid populations we labelled the samples on the base of the factors "Site" and "Period" of collection. Each year we tested the null hypothesis that no differences would exist 
among the coccinellids population, showing the same level of similarity across different vineyards. We performed a permutational multivariate analysis of variance (Permanova) adopting a two-way crossed design with two fixed factors: "Vineyard" with three levels (Md, O, and C) and "Period" again with three levels. The term "Period", considered three levels by grouping three consecutive sample dates, obtaining the "initial" the "medium" and the "late" period. In this way, we reduced the probability to find some significant differences across the high number of dates, just as result of a stochastic event. We considered the period as a fixed factor, because we expected a change in community due to the different period of sampling, further, Malaise catches continuously covered all the experimental period and the "Period" factor does not represent a subsample of a longer range of time. Actually, we were more interested in considering how much of the variation could be assigned to the period and if this factor had a significant interaction with the vineyard factor. In 2012, we performed nine sampling dates. In 2013 we collected samples of ten different dates, so that the Permanova analysis, performed adopting the term "period", produced an unbalanced design with the levels 1 and 2, each one grouping three dates and the level 3 grouping the last four dates. We considered such data adopting sums of square called Types III, where every term in the model is fitted only after taking into account all other terms in the full model. We verified the influence of the dispersion of the data on the Permanova results by testing the homogeneity of their distribution (Permdisp analysis). We choose a $\mathrm{p}$ value $<0.01$ for both the analysis. We compared the estimates of species richness among data sets from the different vineyards by using the two non-parametric estimators Chaol and Chao 2. Chao 1 is considered an abundance estimator, whose calculations are firstly based on the occurrence of "singletons" and "doubletons" species, represented just from one or two specimens across all the samples. The Chao 2 is an incidence estimator and takes into account the rare species observed only in one or two of all the samples. Calculation of the two estimators was performed by running the data of the samples in random order (permute option) for 9,999 times. To relate the coccinellid communities structure to the habitat variable(s), we tested the null hypothesis that such variable(s) were not associated to the coccinellids abundance by using a distance-based linear model analysis, adopting a step-wise selection procedure and an adjusted R2 criteria of selection. $P$ values for testing the null hypothesis were obtained using a permutation method. We adopted a $\mathrm{P}$ value $<0.01$. All these analyses were performed by using the Primer Program v6, 2nd edition (Clarke \& Warwick, 2001; Clarke \& Gorley, 2006) and the Permanova+ for Primer (ANDERSON et al., 2008).

\section{RESULTS}

\section{TOTAL CAPTURES}

A total of 4,923 coccinellids were captured during the two years, 4,057 in 2012 and 866 in 2013. In 2012 we identified 40 species and 38 in 2013. All these species belong to six tribes of Coccinellinae subfamily: Coccinellini, Coccidulini, Platynaspini, Chilocorini, Diomini and Hyperaspini, according to SEAGO et al. (2011). Thirty species were shared between the years; eight species were collected only in 2012 and two only in 2013. Each year, vineyard Md gave more than half of specimens collected, followed by vineyard $\mathrm{O}$ and $\mathrm{C}$ respectively. Total abundance differences among the three vineyards resulted statistically significant (Table 1). Despite the different number of specimens collected from each vineyard, their percentages on the total captures, remained very similar in both the years. A complete list of the captured species in each year is reported in the appendix material at the end of this paper (Tables Appendix 1 and 2).

\section{TRIBES}

Coccidulini and Coccinellini were the most represented tribes, followed by Platynaspini, Chilocorini, Diomini and Hyperaspini. In 2012 and 2013 the number of Coccidulini was markedly higher in $\mathrm{Md}$, followed by $\mathrm{O}$ and $\mathrm{C}$, while populations of Coccinellini showed a lower fluctuation of abundance across the three vineyards (Table 1).

\section{TROPHIC GUILDS}

Composition of the trophic guilds resulted quite similar in both the years. The main group was the aphidophagous covering $80 \%$ of the captures, followed by coccidophagous, mycophagous and acarophagous. Predators of aleyrodids showed a very low presence. This community structure has been maintained across the vineyards $\mathrm{Md}$ and $\mathrm{C}$, whereas in vineyard $\mathrm{O}$ mycophagous was the second abundant group. Only in the vineyard C, acarophagous were higher than 5\% of population (Table 2 ).

\section{MAIN SPECIES}

Hippodamia (Hippodamia) variegata Goeze, Scymnus (Scymnus) frontalis (Fabricius) and Scymnus (Scymnus) interruptus (Goeze) were the most represented species among aphidophagous across the two years.

Nephus (Bipunctatus) bisignatus (Boheman), predator of Planococcus citri (Risso) (Kontodimas et al., 2007), Scymnus (Mimopullus) flagellisiphonatus (Fursch) and Chilocorus bipustulatus (Linnaeus) resulted the most represented species preying on Coccoidea.

Tytthaspis sedecimpunctata (Linnaeus) and Psyllobora vigintiduopunctata (Linnaeus), feeding on fungi of the family Erysiphaceae, were the only mycophagous species (IABLOKOFF-KHNZORIAN, 1982).

Stethorus pusillus (Herbst) and Stethorus gilvifrons (Mulsant) were the only acarophagous species, predators of Tetranychidae mites (BIDDINGER et al., 2009).

Only few specimens of Clitostethus arcuatus (Rossi), predators of Aleyrodids, were collected (Tables Appendix 1 and 2).

\section{STATISTICAL MULTIVARIATE ANALYSIS}

\section{SPECIES AND GUILD MATRICES 2012}

The graphical representation of NMDS, based on the species matrix, showed two separated main groups of samples at the similarity level of $52 \%$. The first, on the upleft corner of the graphic, containing almost all the samples of the vineyards $\mathrm{Md}$ and $\mathrm{O}$ together, and the second group, represented by the left-below group, containing most of vineyard C samples (Fig. I, 1). The same analysis, based on the matrix of the trophic guilds, showed the same groups of samples, but at a similarity level of $72 \%$ (Fig. I, 2).

The Permanova performed on the species matrix, confirmed the separation of the groups, highlighted by the graphical NMDS. Differences with statistical significance resulted for the vineyard factor groups and for the period factor ones without significant interaction (Table 3). The analysis of the dispersion of the samples for the period factor, produced significant differences, resulting in a strong 
Table 1 - Abundance of the different tribes in the three vineyards in 2012 and 2013.

\begin{tabular}{|l|c|c|c|c|c|c|c|}
\hline \hline 2012 & Coccidul. & Coccinel. & Chilocor. & Diomini & Platynasp. & Hyperasp. & Tot \\
\hline Md & 1,445 & 694 & 17 & 4 & 131 & 0 & $\begin{array}{c}2,291 \mathrm{a} \\
(56.47) \\
(56.47 \%)\end{array}$ \\
\hline O & 441 & 482 & 4 & 8 & 33 & 0 & $\begin{array}{c}968 \mathrm{~b} \\
(23.86 \%)\end{array}$ \\
\hline C & 208 & 518 & 2 & 2 & 61 & 7 & $\begin{array}{c}798 \mathrm{c} \\
(19.67 \%)\end{array}$ \\
\hline Tot & 2,094 & 1,694 & 23 & 14 & 225 & 7 & 4,057 \\
\hline$\%$ & 51.61 & 41.75 & 0.57 & 0.35 & 5.55 & 0.17 & 100.00 \\
\hline N. species & 23 & 11 & 1 & 1 & 1 & 1 & 38 \\
\hline 2013 & & & & & & & \\
\hline Md & 390 & 81 & 23 & 1 & 25 & 0 & $\begin{array}{c}520 \mathrm{a} \\
(60.05 \%)\end{array}$ \\
\hline O & 113 & 76 & 4 & 1 & 19 & 0 & $\begin{array}{c}213 \mathrm{~b} \\
(24.59 \%)\end{array}$ \\
\hline C & 45 & 76 & 2 & 0 & 10 & 0 & $\begin{array}{c}133 \mathrm{c} \\
(15.36 \%)\end{array}$ \\
\hline Tot & 548 & 233 & 29 & 2 & 54 & 0 & 866 \\
\hline$\%$ & 63.28 & 26.90 & 3.35 & 0.23 & 6.24 & 0 & 100.00 \\
\hline N. species & 19 & 10 & 1 & 1 & 1 & 0 & 32 \\
\hline
\end{tabular}

Different letters on the totals, represent significant differences (2012: $\mathrm{Md}_{\mathrm{ds}} \mathrm{O} \mathrm{X}^{2}: 537.1, \mathrm{p}<0.001$; $\mathrm{Md}$ vs $\mathrm{C} \mathrm{X}^{2}$ : 721.6, $\mathrm{p}<0.001$; $\mathrm{O}$ vs $\mathrm{C} \mathrm{X}^{2}: 16.4, \mathrm{p}<0.001$, df 1; 2013: $\mathrm{Md}_{\text {vs }} \mathrm{O} \mathrm{X}^{2}: 128.6, \mathrm{p}<0.001$; $\mathrm{Md}$ vs $\mathrm{C}$ $\mathrm{X}^{2}: 213.1, \mathrm{p}<0.001 ;$ O vs C $\mathrm{X}^{2}: 48.1, \mathrm{p}<0.001$, df 1 ).

Table 2 - Abundance of the different guilds in the three vineyards in 2012 and 2013.

\begin{tabular}{|l|c|c|c|c|c|c|c|}
\hline \hline Vineyard 2012 & Ap & Co & My & Ac & Al & O & Tot \\
\hline Md & 2,087 & 133 & 36 & 28 & 1 & 6 & 2,291 \\
\hline O & 483 & 188 & 265 & 29 & 2 & 1 & 968 \\
\hline C & 676 & 24 & 28 & 59 & 2 & 9 & 798 \\
\hline Tot & 3,246 & 345 & 329 & 116 & 5 & 16 & 4,057 \\
\hline N. species & 21 & 9 & 2 & 2 & 1 & 3 & 38 \\
\hline Vineyard 2013 & & & & & & & \\
\hline Md & 414 & 80 & 16 & 9 & 1 & 0 & 520 \\
\hline O & 157 & 22 & 29 & 4 & 1 & 0 & 213 \\
\hline C & 105 & 13 & 6 & 7 & 0 & 2 & 133 \\
\hline Tot & 676 & 115 & 51 & 20 & 2 & 2 & 866 \\
\hline N. species & 19 & 6 & 2 & 2 & 1 & 2 & 32 \\
\hline
\end{tabular}

Ap $=$ Aphidophagous; $\mathrm{Co}=$ Coccidophagous; $\mathrm{My}=$ Mycophagous; $\mathrm{Ac}=$ Acarophagous; $\mathrm{Al}=$ Aleurodophagous; $\mathrm{O}=$ Others (generic predators)

influence on the Permanova results (Table 4). Permanova results for the guilds-based matrix produced the same separation of the sample groups (Table 3 ), without suffering influence by the dispersion of the samples (Table 4).

\section{SPECIES AND GUILDS MATRICES 2013}

The NMDS representation based on species matrix showed two main groups containing most samples at the similarity level of $36 \%$. The first group in the center of the graphic, with almost all samples of the $\mathrm{Md}$ and $\mathrm{O}$ vineyards, separated from a cluster with four sample of $\mathrm{C}$ vineyard on the right part (Fig. II, 1). NMDS based on Guilds matrix produced the same groups of samples at the similarity level of $65 \%$. The first on the left part of the graph grouping most samples of vineyards $\mathrm{Md}$ and $\mathrm{O}$, while the group in the right part of the pictures contains most samples of the vineyard C (Fig. II, 2).

The Permanova performed on the species matrix analysis found a statistical significance for the separation of the groups both for the vineyard than the period factor without significant interaction (Table 5), not suffering a significant difference due to the dispersion of the samples (Table 6). Same results resulted by Permanova based on the Guilds matrix (Tables 5 and 6). 


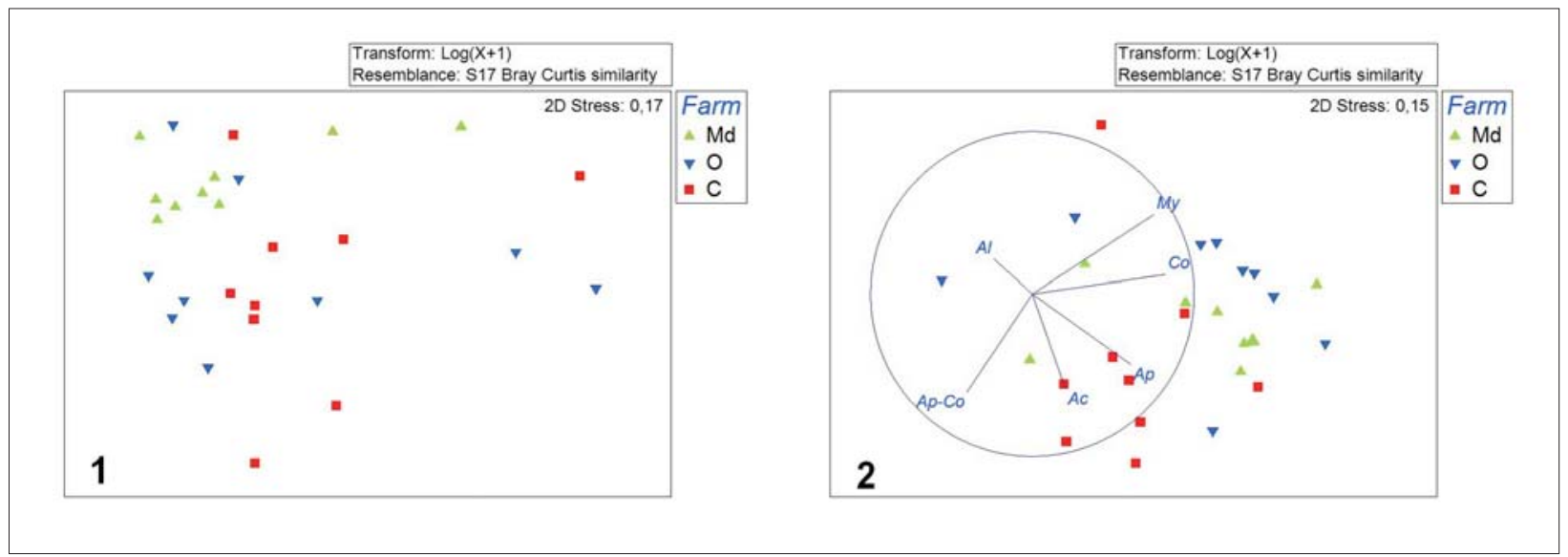

Fig. I - NMDS 2012 graphical representations. 1: graphic based on the Species composition matrix, 2: graphic based on the Guild groups matrix. The same symbols represent samples of the same vineyard. Vectors overlaid in Fig. I 2, represent the Spearman correlation among the guild groups and the positioning of samples.

Table 3 - Permanova analysis two fixed factors, Vineyard and Period for species and guilds matrices.

\begin{tabular}{|l|c|c|c|c|c|c|c|}
\hline \hline Species matrix & df & P & Perms. & Guilds matrix & df & P & Perms. \\
\hline Vineyard & 2 & 0.0001 & 9,935 & Vineyard & 2 & 0.001 & 9,945 \\
\hline Period & 2 & 0.0008 & 9,938 & Period & 2 & 0.004 & 9,955 \\
\hline Vi x Pe & 4 & 0.69 & 9,906 & Vix Pe & 4 & 0.3 & 9,923 \\
\hline Residual & 18 & & & Residual & 18 & & \\
\hline Total & 26 & & & Total & 26 & & \\
\hline
\end{tabular}

Table 4 -Distance-based test for homogeneity of multivariate dispersions. Vineyard and Period for species and guilds matrices.

\begin{tabular}{|c|c|c|c|}
\hline \hline $\begin{array}{c}\text { Species matrix } \\
\text { Vineyard factor }\end{array}$ & Period factor & $\begin{array}{c}\text { Guilds matrix } \\
\text { Vineyard factor }\end{array}$ & Period factor \\
\hline F: $1.54, \mathrm{df1}: 2, \mathrm{df} 2: 24$ & F: $7.65, \mathrm{df1} 1: 2 \mathrm{df} 2: 24$ & F: $0.25, \mathrm{df1}: 2, \mathrm{df2}: 24$ & F: $2.08, \mathrm{df1}: 2, \mathrm{df} 2: 24$ \\
\hline $\mathrm{P}($ perm): 0.4 & P(perm): 0.003 & P(perm): 0.83 & P(perm): 0.18 \\
\hline
\end{tabular}

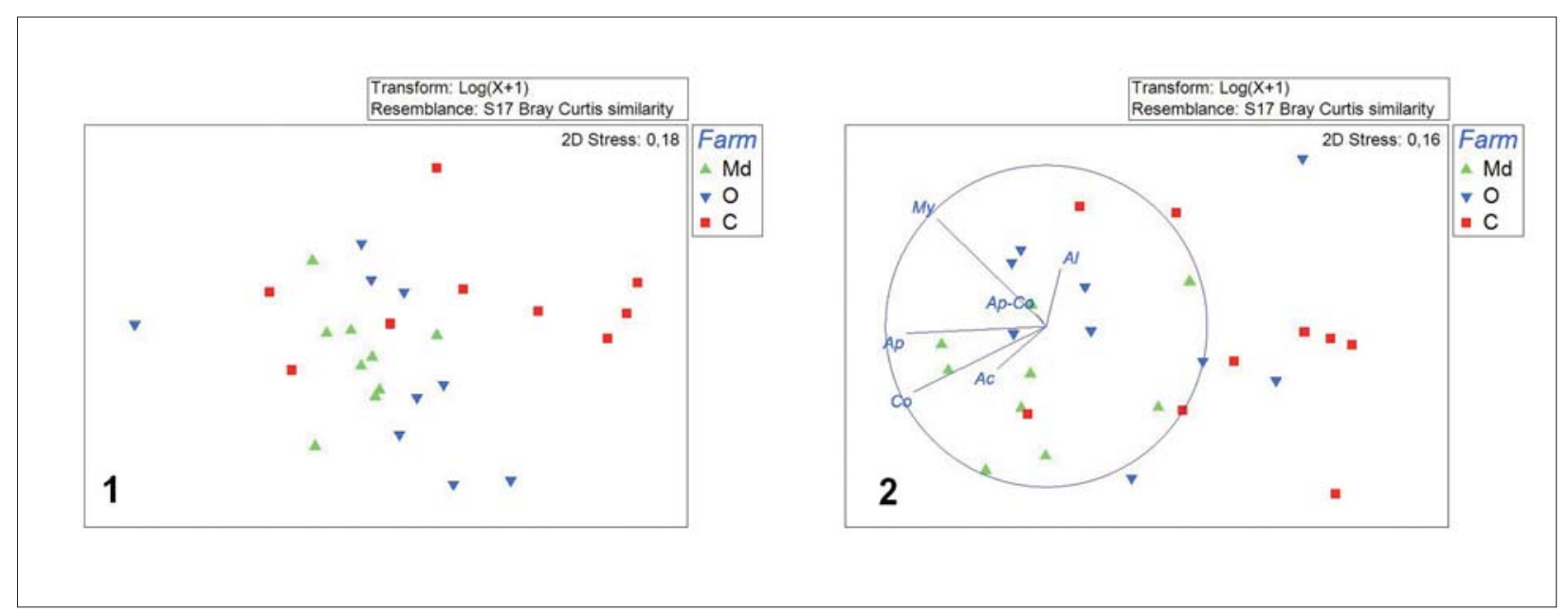

Fig. II - NMDS graphical representations. 1: graphic based on the Species composition matrix, 2: graphic based on the Guild groups matrix. The same symbols represent samples of the same vineyard. Vectors overlaid in Fig. II 2 represent the Spearman correlation among the guild groups and the positioning of samples. 
Table 5 - Permanova analysis two fixed factors, Vineyard and Period for species and guilds matrices.

\begin{tabular}{|c|c|c|c|c|c|c|c|}
\hline \hline Species matrix & df & P & Perms. & Guilds matrix & df & P & Perms. \\
\hline Vineyard & 2 & 0.0001 & 9,921 & Vineyard & 2 & 0.0007 & 9,954 \\
\hline Period & 2 & 0.0001 & 9,927 & Period & 2 & 0.0003 & 9,954 \\
\hline Vix Pe & 4 & 0.0481 & 9,886 & Vix Pe & 4 & 0.89 & 9,944 \\
\hline Residual & 18 & & & Residual & 18 & & \\
\hline Total & 26 & & & Total & 26 & & \\
\hline
\end{tabular}

Table 6-Distance-based test for homogeneity of multivariate dispersions. Vineyard and Period for species and guilds matrices.

\begin{tabular}{|c|c|c|c|}
\hline \hline $\begin{array}{c}\text { Species matrix } \\
\text { Vineyard factor }\end{array}$ & Period factor & $\begin{array}{c}\text { Guilds matrix } \\
\text { Vineyard factor }\end{array}$ & Period factor \\
\hline F: $6.5, \mathrm{df1}: 2, \mathrm{df} 2: 27$ & $\mathrm{~F}: 2.34, \mathrm{df1}: 2, \mathrm{df} 2: 24$ & $\mathrm{~F}: 1.56 \mathrm{df1}: 2, \mathrm{df2}: 27$ & $\mathrm{~F}: 0,41 \mathrm{df1}: 2 ; \mathrm{df} 2: 24$ \\
\hline $\mathrm{P}($ perm $): 0.016$ & $\mathrm{P}($ perm $): 0.15$ & $\mathrm{P}($ perm $): 0.29$ & $\mathrm{P}($ perm $): 0.7$ \\
\hline
\end{tabular}

\section{SPECIES RICHNESS ESTIMATORS}

In 2012 non-parametric estimators Chao 1 and Chao 2 showed an increasing tendency in vineyard Md, suggesting that more species $(7-9)$ could be found over the number of the observed species. In vineyard $\mathrm{O}$ they stabilize, suggesting that from five to ten additional species still remain undetected. In vineyard $\mathrm{C}$ both estimators showed a reduction trend suggesting that no more species have to be found (Fig. III).

In 2013 estimators Chao 1 and Chao 2, very quickly increased and stabilize in vineyards $\mathrm{Md}$ and $\mathrm{O}$, suggesting that from 2 to 5 further species could be found respect to the Sobs. Again, both estimators showed a reduction trend in vineyard $\mathrm{C}$, suggesting that no additional species have to be found (Fig. IV).

\section{DISTANCE BASED LINEAR MODEL}

In 2012 the marginal test shows that only the variable herbs had a significant relationship with the derived multivariate data cloud of the species and alone explains more than $12 \%$ of the variability in data cloud. No significant relationships emerged by considering the other habitat variables. Very similar consideration resulted by analyzing the results of 2013. Again, the variable herbs produced a significant relationship with the species data cloud, explaining more $18 \%$ of all the data cloud variability (Table 7 ).

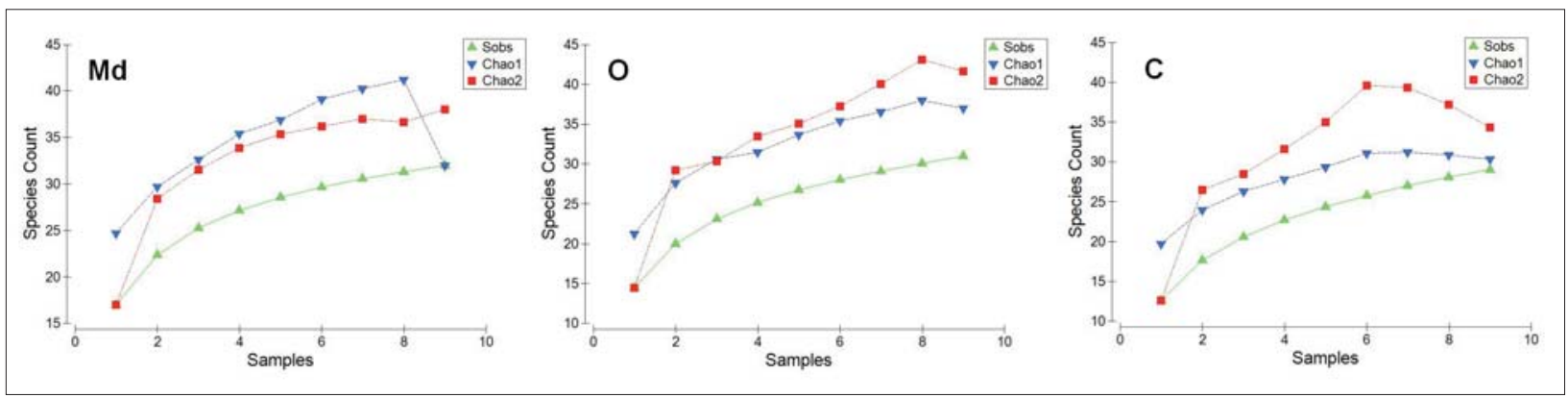

Fig III - Functions describing the non-parametric species richness estimators: Chao 1: blue triangles dotted line, Chao 2: squares dotted line, Species observed (Sobs): green triangles dotted line.
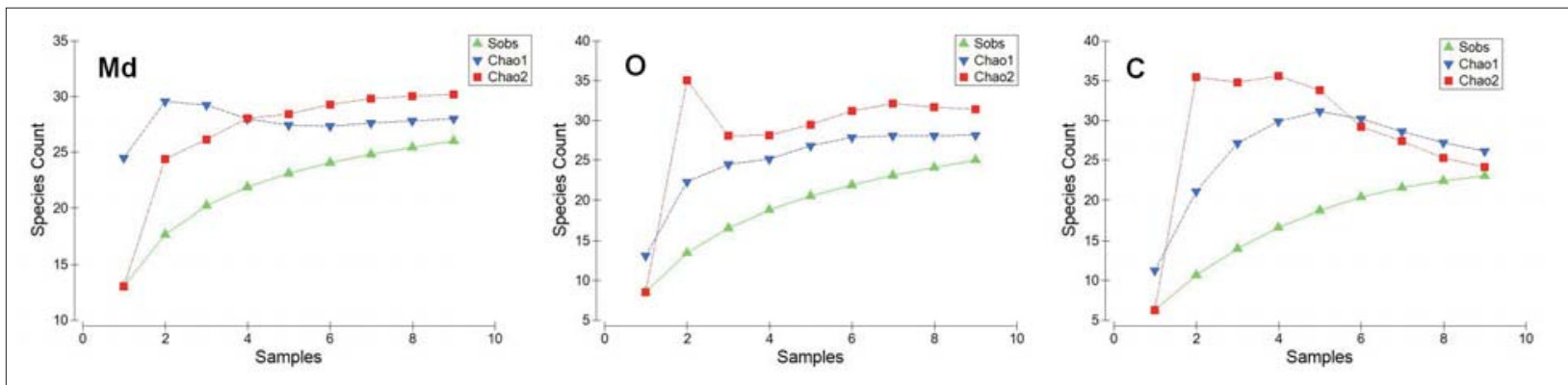

Fig IV - Functions describing the non-parametric species richness estimators: Chao 1: blue triangles dotted line, Chao 2: squares dotted line, Species observed (Sobs): green triangles dotted line 
Table 7 - Distance-based linear model for habitat variables using step-wise selection procedure. Boldface values are statistical significant.

\begin{tabular}{|c|c|c|c|c|c|c|c|c|}
\hline \multicolumn{5}{|c|}{2012} & \multicolumn{4}{|c|}{2013} \\
\hline Variable & $\mathrm{SS}$ (trace) & Pseudo-F & $\mathrm{P}$ & Prop. & $\mathrm{SS}$ (trace) & Pseudo-F & $\mathrm{P}$ & Prop. \\
\hline Vineyard & $2,540.3$ & 1.86 & 0.07 & $6.91 \mathrm{E}-02$ & $4,041.4$ & 1.59 & 0.13 & $6.00 \mathrm{E}-02$ \\
\hline Trees & $2,103.4$ & 1.52 & 0.14 & $5.72 \mathrm{E}-02$ & 6,483 & 2.67 & 0.012 & $9.6 \mathrm{E}-02$ \\
\hline Bushes & $2,495.5$ & 1.82 & 0.087 & $6.79 \mathrm{E}-02$ & $4,045.6$ & 1.56 & 0.12 & $6.01 \mathrm{E}-02$ \\
\hline Herbs & $4,533.7$ & 3.52 & 0.002 & 0,12 & 11,835 & 5.3 & 0.0002 & 0.18 \\
\hline
\end{tabular}

\section{DISCUSSION}

The fluctuation of insect populations through time and space is a common phenomenon, influenced by many ecological factors (LONI \& LUCCHI, 2014) and well explains the drastic fall of the total captures in 2013. Nevertheless, the percentage contribution to the total captures of each vineyard remained the same. These data describe an ecological structure of populations well established and integrated with the habitat hosting them. The high number of species observed (40), covering about a third of all the species described in Italy (CANEPARI, 2013), represents a very interesting result by considering the reduced surface of sampled area. Moreover it is interesting to underline the presence of the exotic species Harmonia. axyridis (Pallas), introduced in Italy in greenhouses for biocontrol between 1995 and 1999 and recorded in natural environments since 2006 (BuRGio et al., 2008) and nowadays well spread all over Italian territory (MENICHETTI et al., 2015). H. axyridis is a generic predator whose feeding action involves the aphid Daktulosphaira (=Viteus) vitifoliae (Fitch) (KoGEL et al., 2013). This exotic species need to be monitored because of its capacity to taint the resulting wine with alkaloids flavor (EJBICK, 2003; KoCH, 2003; PICKERING et al., 2004; Galvan et al., 2007; Pfeiffer et al., 2012). The three vineyards showed a decreasing abundance of ladybirds population, passing from $\mathrm{Md}$ to $\mathrm{O}$ and $\mathrm{C}$ respectively. This is consistent with the three different habitat structures and the management systems adopted. The extended herbaceous cover of MD vineyard supported the significatively higher ladybirds number collected, in comparison with $\mathrm{O}$ and even more with $\mathrm{C}$ vineyard, both tilled into the rows. This result is in agreement with what described by other Authors about the importance of herbs cover for predators (RoOT, 1975; LANDIS, 1994; AltiERI, 1999; NichOls et al., 2000; 2001; 2008; Thomson \& Hoffman, 2009). The smallest population of $\mathrm{C}$ vineyard also evidences the coccinellids sensitiveness to the use of chemicals in agreement with YARDIM \& EDWARDS (1998), OBRYCKI \& KRING (1998), RODRIGUEZ et al. (2003), SANTOS et al. (2007; 2010).

Coccidulini and Coccinellini always resulted the most represented tribes in agreement with Italian coccinellids fauna (Audisio et al., 1995). The Coccidulini number decreased passing from $\mathrm{Md}$, to $\mathrm{O}$ and $\mathrm{C}$ vineyards respectively, in line with the general trend of the entire ladybirds population. Coccinellini abundance showed a low abundance fluctuation all over the three vineyards, without to be affected by the different habitat structures and management systems as possible consequence of their lower susceptibility to chemicals, due to their higher average body sizes. Indeed it is documented that the toxicity of an insecticide is related to the size of the organism exposed (OBRYCHI \& KRING, 1998; Gilbert, 2004; Kraiss \& CULlen, 2008; ZhU, 2008).
Aphidophagous ladybirds were always the prevalent guild in each vineyard in agreement with HoDEK \& HONĔK (2009) about the distribution of coccinellids trophic guilds in temperate regions. Predators of aleyrodids were very scarce and this could be due to the reduced occurrence of these phytophagous into the vineyards (PAJOvic et al., 2012). Also acarophagous ladybird populations, were quite reduced and, only in the conventional vineyard $(\mathrm{C})$, this component of predators was well represented. Their higher presence in this vineyard could represent the ecological answer to a major concentration of phytophagous mites, due to the mites stimulant-action, induced by the adoption of chemical insecticides (VAN DE VRIE et al., 1972; GIROLAMI, 1981; GRUYS, 1982; ROSSI \& CONTI, 1997).

The analysis of the coccinellids community structure allowed to discriminate very well the conventional $\mathrm{C}$ vineyard by the two organic $\mathrm{Md}$ and $\mathrm{O}$ that shared a more similar coccinellid community structure. The higher level of similarity of the samples composition, resulted by the analysis of the trophic guilds of the species, suggested that the changes of the community structure, in terms of species composition, did not affect the functional structure of the population in agreement with a functional study approach of biodiversity (LAURETO et al., 2015). That is consistent with a good resilience of the ecosystem, where the lost or reduction of one species can be compensated by the arrival or the growth population of other species that have similar functions (NAEEM, 1998; SCHMID et al., 2009; Mori et al., 2013).

According to the two non-parametric species estimators, a richer community of coccinellids is expected in the two organic vineyards (MD and $\mathrm{O}$ ), supporting that the organic management offers more suitable conditions to host a rich biodiversity.

\section{CONCLUSIONS}

Herbs cover resulted a crucial resource in sustaining an abundant coccinellids population as reported by other authors (AltiERI, 1999; NiCHOLS et al., 2000; 2001; 2008). Coccinellids resulted a good bioindicators group that resulted sensitive to the use of chemicals. The analysis of their community structure, based on the compositional and functional biodiversity, allows to discriminate different environments and to obtain useful information about the resilience of an agroecosystem.

\section{REFERENCES}

Ali M., Perveen, R., Yousuf, M.J., Khawja, S., Amin, M., 2014 - Predatory potential of five coccinellid predators against cotton mealy bug Phenacoccus solenopsis 
(Tinsley) in laboratory and field conditions from Sindh Pakistan. Pakistan. - Pak. Ent., 36: 7-12.

AltiERI M.A., 1999 - The ecological role of biodiversity in agroecosystems. - Agriculture, Ecosystems and Environment, 74: 19-31.

Altieri M.A., CURE J.R., Garcia M.A., 1993 - The role and enhancement of parasitic Hymenoptera biodiversity in agroecosystems. In: La Salle, J., Gauld I.D. (Eds.), Hymenoptera and biodiversity. Wallingford, UK: CAB international, pp. 257-275.

ANDERSEN A.N., 1999 - My bioindicators or yours? Making the selection. - J. Ins. Coserv., 3: 1-4.

Anderson M., Gorley, R.N., Clarke, R.K., 2008 Permanova+ for Primer: Guide to Software and Statistical Methods. Primer-E: Plymouth, UK.

Audisio P., Canepari C., De Biase A., Poggi R., Ratti E., Zampetti M.F., 1995 - Coleoptera Polyphaga XI (Clavicornia II). In: Minella, A., Ruffo, S., La Posta, S. (Eds), Checklist delle specie della fauna italiana, 56: 1014. Calderini, Bologna.

Bentley W.J., Varela L., DaAne K.M., 2005 - Grapes insects ecology and control. In: Pimentel D (Ed), Encyclopedia of Pest Management. Taylor \& Francis, New York, pp: 1-8. doi: 10.1081/E-EPM-120041132

Biddinger D.J., Weber D.C., Hull L.A., 2009 Coccinellidae as predators of mites: Stethorini in biological control. - Biological Control, 51: 268-283.

Bolduc E., Buddle C.M., Bostonian N. J., Vincent C., 2005 - The ground dwelling spiders (Araneae) of two vineyards in southern Quebec. - Environ. Entomol., 34: 635-645.

Bostonian N.J., Vincent C., Goulet G., Lesage L., Lasnier J., Bellemare J., Mauffette Y., 2003 - The arthropod fauna of Quebec vineyards with particular reference to phytophagous species. - J. Econom. Entomol., 96: 1221-1229.

Bouchard P., Lesage, L., Goulet, H., Bostanian, N.J., Vincent, C., ZMUDZINSKA, A., LASNIER, J., 2005 - Weevil (Coleoptera: Curculionoidea) diversity and abundance in Quebec vineyards. - Ann. Entomol. Soc. Am. 98: 565574.

Burgio G., Santi, F., Lanzoni, A., Masetti, A., De Luigi, V., Melandri, M., MainI, S., 2008 - Harmonia axyridis recordings in northern Italy. - Bull. Insectol., 61: 361364.

Burgio G., Marchesini, E., Reggiani, N., Montepaone, G., Schintti, P., Sommaggio, D., 2016 - Habitat management of organic vineyard in Northern Italy: the role of cover plants management on arthropod functional biodiversity. - Bulletin of entomological research, 106 (6): 759-768.

CANEPARI C., 1983 - Le specie italiane del gruppo dello Scymnus frontalis Fab. Con descrizione di due nuove specie (Coleoptera Coccinellidae). - Giornale Italiano di Entomologia, 1(4): 179-204.

CANEPARI C., 2000 - The Nephus subgenus Sidis in Italy (Coleoptera Coccinellidae). - Boll. Soc. entomol. Ital., 132 (1): 49-62.

CANEPARI C., 2013 - Fauna Europaea: Coccinellidae. In: Karsholt, O., Nieukerken, E.J. van. Fauna Europaea: Lepidoptera, Coleoptera. Fauna Europaea version 2017.06, https://fauna-eu.org

CAnepari C., Tedeschi, M., 1977 - Le sottospecie del Nephus quadrimaculatus (Herbst) (Coleoptera Coccinellidae). - Memorie della Società Entomologica Italiana, 55 [1976]: 101-105.

Canepari C., Fürsch, H., \& Kreissl, E., 1985 - Die
Hyperaspis-Arten von Mittel, West-und Südeuropa. Systematik und verbreitung (Coleoptera Coccinellidae). Giornale italiano di Entomologia, 2(9): 223-252.

Canovai R., Loni, A., Gandini, L., Lucchi, A., 2014 Ladybirds in Tuscan vineyards (Coleoptera: Coccinellidae). Integrated protection and production in Viticulture. - IOBC-WPRS Bulletin, 15: 241-244.

Clarke K.R., Gorley, R.N., 2006 - Primer v6: User Manual/Tutorial. - Primer-E, Plymouth, UK.

Clarke K.R., Warwick, R.M., 2001 - Change in marine communities: an approach to statistical analysis and interpretation. 2nd Edition - PRIMER-E Ltd: Plymouth, United Kingdom.

CODERRE D., 1988 - Effectiveness of aphidophagous insects in maize. In: Niemczyk, E., Dixon, A.F.G. (Eds.), Ecology and Effectiveness of Aphidophaga. SPB Academic Publishing, The Hague, The Netherlands, pp. 211-214.

EJBICH K., 2003 - Producers in Ontario and northern US bugged by bad odors in wines. - The Wine spectator, 28 (2): 16.

EVANS E.W., 2009 - Lady beetles as predators of insects other than Hemiptera. - Biological Control 51: 25-267.

Fraser S.E., Dytham, C., Mayhew, P.J., 2007 Determinants of parasitoid abundance and diversity in woodland habitats. - Journal of applied ecology, 44 (2): 352-361.

Fraser S.E., Dytham, C., MaYhew, P.J., 2008 - Patterns in the abundance and distribution of ichneumonid parasitoids within and across habitat patches. Ecological entomology, 33 (4): 473-483.

FÜRSCH H., 1965 - Die paläarktischen Arten der Scymnus bipunctatus-Gruppe und die europäischen Vertreter der Untergattung Sidis. - Mitteilungen der Münchner Entomologischen Gesellschaft, 54: 178-213.

Fursch H., Kreissl, E., \& CAPRA, F., 1967 - Revision einiger europaischer Scymnus (s. str.)-Arten (Coleoptera, Coccinellidae). - Mitteilungen Abteilung fur Zoologie. Landesmuseum Joanneum. Graz. Bd, 28: 207-259.

Galvan T.L., Burkness, E.C., Vickers, Z., Stenberg, P., Mansfield, A.K., Hutchison, W.D., 2007 - Sensorybased action threshold for multicolored Asian lady beetlerelated taint in winegrapes. - American journal of enology and viticulture, 58 (4): 518-522.

Gerson U., Mescheloff, E., Dubitzki, E., 1975 - The introduction of Neodusmetia sangwani (Rao) (Hymenoptera: Encyrtidae) into Israel for the control of the Rhodesgrass scale, Antonina graminis (Maskell) (Homoptera: Pseudococcidae). - Journal of Applied Ecology, 12 (3): 767-779.

Gilbert S. G., 2004 - A small dose of toxicology: The health effects of common chemicals. CRC Press.

GIROLAMI V., 1981 - Danni, soglie di intervento, controllo degli acari della vite. - Proceedings of the III incontro su La difesa integrata della vite, Latina, Italy: 111-143.

Goulet H., Lesage L., Bostanian N.J., Vincent C., LASNIER J., 2004 - Diversity and seasonal activity of ground beetles (Coleoptera: Carabidae) from two vineyards in southern Quebec. - Ann. Entomol. Soc. Am., 97: 1263-1272.

Gourreau J.M., 1974 - Systématique de la tribu des Scymnini (Coccinellidae) - Ann. Zool. Ecol. Anim. I.N.R.A. - Numéro Hors Series: 1-122.

GRUYS P., 1982 - Hits and misses. The ecological approach to pest control in orchards. -Entomologia experimentalis et applicata, 31 (1): 70-87.

Hemchandra O., Kalita, J., Singh, T.K., 2010 Biodiversity of aphidophagous Coccinellids and their role 
as bioindicators in agro-forest ecosystem. - The Biascan, Special Issue 1: 115-122.

Hodek I., HonĚK, A., 2009 - Scale insects, mealybugs, whiteflies and Psyllids (Hemiptera, Sternorrhyncha) as prey of ladybirds. - Biological control, 51: 232-243.

IABLOKOFF-KHNZORIAN S.M., 1982 - Les coccinelles: coléoptères-coccinellidae: tribu coccinellini des régions paléarctique et orientale. - Société nouvelle des éditions Boubée, Paris, pp 568.

IPERTI G., 1999 - Biodiversity of predaceous coccinellidae in relation to bioindication and economic importance. Agricolture, - Ecosystems and Environment, 74: 323-342.

Joshi P., Khamashon, L., Kaushal, B.R., Kishore, K., 2012 - New Addition of Coccinellid Beetkles (Coleoptera: Coccinellidae) to the already reported Species from Uttarakhand, India. - Nature and Science, 10 (6): 26-30.

Klausnitzer B., Klausnitzer, H., 1997 - Marienkäfer (Coccinellidae). 4. Überarbeitete Auflage. Die Neue Brehm-Bücherei Bd. 451. - Westarp Wissenschaften, Magdeburg, Germany, pp 175.

Koch R.L., 2003 - The multicolored Asian lady beetle, Harmonia axyridis: A review of its biology, use in biological control and no-targets impacts. - J. Insect Sci, 3 (32): 1-16

Kögel S., Schieler, M., Hoffmann, C., 2013 - The ladybird beetle Harmonia axyridis (Coleoptera:Coccinellidae) as a possible predator of grape phylloxera Daktulosphaira vitifoliae (Hemiptera: Phylloxeridae). - Eur. J. Entomol. 110 (1): 123-128.

Kontodimas D.C., Milonas, P.G., Stathas, G.J., Economou, L.P., KaVAllieratus, N., 2007 - Life table parameters of the pseudococcid predators Nephus includens and Nephus bisignatus (Coleoptera: Coccinelidae). - Eur. J. Entomol., 104: 407-415.

KovÁŘ I., 1996 - Phylogeny. In: Hodek, I., Honěk, A. (Eds.), Ecology of Coccinellidae. - Series Entomologica. Springer, Dordrecht: Kluver Academic Pub. 54: 19-31.

Kraiss H., Cullen, E.M., 2008 - Efficacy and nontarget effects of reduced-risk insecticides on Aphis glycines (Hemiptera: Aphididae) and Its biological control agent Harmonia axyridis (Coleoptera: Coccinellidae). - Journal of economic entomology, 101 (2): 391-398.

Lami F., Masetti, A., Neri, U., Lener, M., Staiano, G., Arpaia, S., Burgio, G., 2016 - Diversity of Coccinellidae in ecological compensation areas of Italy and overlap with maize pollen shedding period. - Bulletin of Insectology 69 (1): 49-57.

LANDIS D.A., 1994 - Arthropod sampling in agricultural landscapes: ecological considerations. - In: Pedigo, L.P., Buntin, G.D. (Eds.), Handbook of sampling methods for Arthropods in Agriculture. CRC Press, Boca Raton, Florida USA, pp. 15-31.

Laureto L.M.O., Cianciaruso, M.V., Samia, D.S.M., 2015 - Functional diversity: an overview of its history and applicability. - Natureza \& Conservação, 13 (2): 112-116.

Lesage L., Bouchard, P., Goulet, H., 2008 - Leaf beetle diversity and abundance in two Quebec vineyards (Coleoptera: Chrysomelidae). - Nouv. Rev. Entomol., 104: 737-743.

Loni A., Canovai, R., Gandini, L., Lucchi, A., 2014 Aphidophagous insects in differently managed vineyards. Integrated protection and production in Viticolture, IOBC-WPRS Bulletin, 105: 245-248.

LONI A., LUCCHI, A., 2014 - Hymenoptera Parasitoids, a Suitable Biodiversity Resource for Vineyards Environmental Discrimination. - Journal of Agricultural Science, 6 (12): 36-52.
Lucas É., Vincent, C., Labrie, G., Chouinard, G., Fournier, F., Pelletier, F., Bostanian, N.J., Coderre, D., Mignault, M.P., Lafontaine, P., 2007 - The multicolored Asian ladybeetle Harmonia axyridis (Coleoptera: Coccinellidae) in Quebec agroecosystems ten years after its arrival. - Eur. J. Entomol., 104: 737743.

MaJerus M.E.N., 1994 - Ladybirds. New naturalist series, 81. - Harper Collins Publishers, London.

Menalled F.D., Marino, P.C., Gage, S.H., Landis, A.D., 1999 - Does agricultural landscape structure affect parasitism and parasitoids diversity? - Ecol. Appl., 9 (2): 634-641. http://dx.doi.org/10.189/1051-0761 (1999)009 [0634:DALSAP]2.0.CO;2

Menichetti M., Ancilotto, L., Russo, D., Bertolino, S., Bettacchiol, G., Mori E., 2015 - New records of the alien invasive species Harmonia axyridis (Pallas, 1773) in Italy (Coleoptera: Coccinellidae). - Onychium, 11: 139-142.

Mori A.S., FurukaWA, T., SASAKI, T., 2013 - Response diversity determines the resilience of ecosystems to environmental change. - Biological reviews 88 (2): 349-364.

NAEem S. 1998 - Species redundancy and ecosystem reliability. - Conservation biology, 12 (1): 39-45.

Nicholls C.I., PArrella, M.P., Altieri, M.A., 2000 Reducing the abundance of leafhoppers and trips in a northern California organic vineyard through maintenance of full season floral diversity with summer cover crops. - Agric. For. Entomol. 2: 107-113.

Nicholls C.I., Parrella, M., Altieri, M.A., 2001 - The effects of a vegetational corridor on the abundance and dispersal of insect biodiversity within a northern California organic vineyard. - Landscape ecology, 16 (2): 133-146.

Nicholls C.I., Altieri, M.A., PonTi, L., 2008 - Enhancing plant diversity for improved insect pest management in northern California organic vineyards. - Acta horticulturae, 785: 263-278.

OBrycki J.J., HaRwoOd, J.D., KRING, T.J., O’NeIL, R.J., 2009 - Aphidophagy by Coccinellidae: Application of biological control in agroecosystems. - Biological Control, 51: 244-254.

Obrycki J.J., KRInG, T.J., 1998 - Predaceous Coccinellidae in Biological Control. - Annu. Rev. Entomol. 43: 295-321.

OBRYcKi J.J., HaRwoOd, J.D., KRING, T.J., O’NeIL, R.J., 2009 - Aphidophagy by Coccinellidae: Application of biological control in agroecosystems. - Biological Control 51: 244-254

Pajovic I., Petric, D., Pesic, V., Pajovic, L., 2012 Comparison of cabbage and vineyard entomofauna in Podgorica region, Crna Gora (Montenegro). - Natura Montenegrina,11 (3): 531-559.

Pfeiffer D.G., Leskey, T.C., Burrack, H.J., 2012 Threatening the harvest: The threat from three invasive insects in late season vineyards. - In: Arthropod Management in Vineyards. Springer, Dordrecht, pp. 449474.

Pickering G., Lin, J., Riesen, R., Reynolds, A., Brindle, I., SoleAs, G., 2004 - Influence of Harmonia axyridis on the sensory properties of white and red wine. - American Journal of Enology and Viticulture, 55 (2): 153-159.

PorTA A., 1929 - Fauna Coleopterorum Italica - vol. 3 Divericornia. Piacenza, pp. 242-277.

PREACHER K. J., 2001 - Calculation for the chi-square test: An interactive calculation tool for chi-square tests of goodness of fit and independence - [Computer software]. Available from http://quantpsy.org.). 
Rodriguez E., PeÑa, A., Raya, A.J.S., CAmPos, M., $2003-$ Evaluation of the effect on arthropod populations by using deltamethrin to control Phloeotribus scarabaeoides Bern.(Coleoptera: Scolytidae) in olive orchards. Chemosphere, 52 (1): 127-134.

Root R.B., 1975 - Some consequences of ecosystem texture. - In: Proceedings of a Conference on Ecosystem Analysis \& Prediction. Levin, S.A. Ed. Ind. Appl. Math. Philadelphia, PA.

Rossi E., ConTI, B., 1997 - Valutazione della risposta ad alcuni acaricidi e insetticidi in ceppi di Tetranychus urticae Koch (Acarina: Tetranychidae) e del suo predatore Phytoseiulus persimilis Athias-Henriot (Acarina: Phytoseiidae). - Frustula Entomologica, 20: 168-177.

SAHAROUi L., 1994. - Inventaire et étude de quelques aspects bioécologiques des coccinelles entomophages (Coleoptera, Cocinellidae) dans l'Algérois. - Journal of African Zoology, 108 (6): 537-546.

Saharaoui L., Gourreau, J.M., 1998 - Les coccinelles d'Algérie: inventaire préliminaire et régime alimentaire (Coleoptera, Coccinellidae). - Bulletin de la Société entomologique de France, 103 (3): 213-224.

Santos S.A.P., Pereira, J.A., Torres, L.M., Nogueira, A.J.A., 2007 - Evaluation of the effects, on canopy arthropods, of two agricultural management systems to control pests in olive groves from north-east of Portugal. - Chemosphere 67 (1): 131-139.

SAntos S.A.P., Pereira, J.A., Raimundo, A., Torres, L.M., Nogueira, A.J.A., 2010 - Response of coccinellid community to the dimethoate application in olive groves in northeastern Portugal. - Spanish Journal of Agricultural Researh, 8 (1): 126-134.

SASAJI H., 1968 - Phylogeny of the family Coccinellidae(Coleoptera). - Etizenia, 35: 1-37.

Schmid B., Balvanera, P., Cardinale, B.J., Godbold, J., Andrea B. Pfisterer, A.B., Raffaelli, D., Solan, M., SRIVASTAVA, D.S., 2009 - Consequences of species loss for ecosystem functioning: meta-analyses of data from biodiversity experiments. - In: Naeem, S., Bunker, D. E., Hector, A., Loreau, M., Perrings, C. (Eds.), Biodiversity, ecosystem functioning, and human wellbeing: an ecological and economic perspective. Oxford University Press, pp.: 14-29.

Seago A.E., Giorgi, J.A., Li, J.,Ślipiński, A., 2011 Phylogeny, classification and evolution of ladybird beetles (Coleoptera: Coccinellidae) based on simultaneous analysis of molecular and morphological data. - Mol. Phylogenet. Evol. 60 (1): 137-51.
Shantibala K., Singh, L.S., Singh, T.K., Chitra Devi, L., 1997 - Impact of predators and climatic factors on the population density of the aphid, Cervaphis rappadi indica Basu on Cajanus cajan. Mill. - J. Aphidol., 11: 133-137.

ŚlIPIŃSKI A., 2007 - Australian ladybird beetles (Coleoptera: Coccinellidae): their biology and classification. - Australian Biological Resources Study; Canberra, pp 288.

Ślipiński A., TOMASZEWSKA, W., 2010 - Coccinellidae Latreille, 1802. . In: Leschen, R.A B., Beutel, R.G., Lawrence, J.F. (Eds.), Handbook of zoology, coleopteran, Vol. 2. Walter de Gruyter, Berlin, pp. 454-472

Sommaggio D., Burgio, G., 2014 - The use of Syrphidae as functional bioindicator to compare vineyards with different managements. - Bulletin of Insectology, 67 (1): 147-156.

Thomson L.J., Hoffmann, A.A., 2009 - Vegetation increases the abundance of natural enemies in vineyards. - Biological Control, 49 (3): 259-269.

Van de Vrie M., McMurtry, J., Huffaker, C., 1972 Ecology of tetranychid mites and their natural enemies: A review: III. Biology, ecology, and pest status, and hostplant relations of tetranychids. - Hilgardia, 41 (13): 343432.

Vincent C., Isaacs, R., Bostanian, N.J., 2012 - Principles of Arthropod Pest Management in Vineyards. - In: Bostanian N.J., Vincent C., Isaacs R. (Eds.), Arthropod Management in Vineyards: Pests, Approaches and Future Directions, Springer Science + Business Media, pp.: 1-17. http://dx.doi.org/10.1007/978-94-007-4032_1

WisE I.L., LAmB, R.J., KenAshuK, E.O., $19 \overline{95}$ - Effects of the Potato aphid Macrosiphum euphorbiae Thomas (Homoptera: Aphididae) on oilseed flax, and stagespecific thresholds for control. - The Canadian Entomol., 127: 213-224.

YARDIM E.N., EDwards, C.A., 1998 - The influence of chemical management of pests, diseases and weeds on pest and predatory arthropods associated with tomatoes. - Agriculture, ecosystems \& environment, 70 (1): 31-48.

ZahoOr M.K., Suhail, A., IQbal, J., ZulfaQAR, Z., AnWar, M., 2003 - Biodiversity of predaceous Coccinellids an their role as bioindicators in an Agro-system. International Journal of Agriculture \& Biology, 5 (4): $55-$ 59.

ZHU K.Y., 2008 - Insecticide bioassay. - In: Encyclopedia of Entomology, Capinera J.L., editor., Springer, Dordrecht, pp.: 1974-1976. 
Table Appendix 1-2012 - Ladybird species collected in vineyards studied and their guild .

\begin{tabular}{|c|c|c|c|c|}
\hline Tribe Chilocorini & $\mathrm{Md}$ & $\mathrm{O}$ & $\mathrm{C}$ & Tr. guild \\
\hline Chilocorus bipustulatus (Linnaeus) & 17 & 4 & 2 & $\mathrm{Co}$ \\
\hline \multicolumn{5}{|l|}{ Tribe Coccidulini } \\
\hline Stethorus gilvifrons (Mulsant) & 17 & 12 & 28 & $\mathrm{Mi}$ \\
\hline Stethorus pusillus (Herbst) & 11 & 17 & 31 & $\mathrm{Mi}$ \\
\hline Scymnus (Mimopullus) flagellisiphonatus (Fursch) & 28 & 102 & 5 & Co \\
\hline Scymnus (Neopullus) haemorrhoidalis Herbst & 36 & 14 & 2 & Ap \\
\hline Scymnus (Neopullus) limbatus Stephens & 5 & 1 & 2 & $\mathrm{O}$ \\
\hline Scymnus (Pullus) auritus Thunberg & 13 & 43 & 9 & Ap \\
\hline Scymnus (Pullus) fraxini Mulsant * & - & - & 1 & Co \\
\hline Scymnus (Pullus) subvillosus (Goeze) & 7 & 2 & 3 & Ap \\
\hline Scymnus (Pullus) suturalis Thunberg & 1 & - & - & $\mathrm{O}$ \\
\hline Scymnus (Scymnus) apetzi Mulsant & 27 & 4 & 8 & Ap \\
\hline Scymnus (Scymnus) apetzoides Capra e Fursch & 3 & 2 & - & Ap \\
\hline Scymnus (Scymnus) femoralis (Gyllenhal) & 7 & 17 & - & Ap \\
\hline Scymnus (Scymnus) frontalis (Fabricius) & 653 & 70 & 50 & Ap \\
\hline Scymnus (Scymnus) interruptus (Goeze) & 514 & 66 & 27 & Ap \\
\hline Scymnus (Scymnus) marginalis (Rossi) & 3 & 3 & 3 & Ap \\
\hline Scymnus (Scymnus) rubromaculatus (Goeze) & 13 & 4 & 1 & Ap \\
\hline Scymnus (Scymnus) rufipes (Fabricius) & 22 & 8 & 22 & Ap \\
\hline Nephus (Nephus) quadrimaculatus (Herbst) * & - & 1 & - & Co \\
\hline Nephus (Bipunctatus) bipunctatus (Kugelann) & - & 1 & 1 & Co \\
\hline Nephus (Bipunctatus) bisignatus (Boheman) & 79 & 71 & 13 & Co \\
\hline Scymniscus anomus (Mulsant) * & 1 & - & - & Co \\
\hline Clitostethus arcuatus (Rossi) & 1 & 2 & 2 & $\mathrm{Al}$ \\
\hline Rhyzobius lophanthae (Blaisdell) & 4 & 1 & - & Co \\
\hline \multicolumn{5}{|l|}{ Tribe Coccinellini } \\
\hline Hippodamia (Hippodamia) variegata Goeze & 445 & 82 & 381 & Ap \\
\hline Hippodamia (Hemisphaerica) tredecimpunctata Linnaeus & 1 & - & 1 & Ap \\
\hline Adalia (Adalia) decempunctata (Linnaeus) ${ }^{*}$ & - & 1 & - & Ap \\
\hline Tytthaspis sedecimpunctata (Linnaeus) & 5 & 245 & 22 & My \\
\hline Coccinella (Coccinella) septempunctata Linnaeus & 9 & 24 & 43 & Ap \\
\hline Coccinula quatuordecimpustulata (Linnaeus) & 5 & 20 & 2 & Ap \\
\hline Oenopia conglobata (Linnaeus) & 1 & - & - & Ap \\
\hline Harmonia axyridis (Pallas) & - & 1 & 3 & Ap \\
\hline Harmonia quadripunctata (Pontoppidan) * & 1 & - & - & Ap \\
\hline Propylea quatuordecimpunctata (Linnaeus) & 196 & 89 & 60 & Ap \\
\hline Psyllobora vigintiduopunctata (Linnaeus) & 31 & 20 & 6 & My \\
\hline \multicolumn{5}{|l|}{ Tribe Diomini } \\
\hline Diomus rubidus (Motschulsky) & 4 & 8 & 2 & Co \\
\hline \multicolumn{5}{|l|}{ Tribe Hyperaspini } \\
\hline Hyperaspis chevrolati Canepari * & - & - & 7 & $\mathrm{O}$ \\
\hline \multicolumn{5}{|l|}{ Tribe Platynaspini } \\
\hline Platynaspis luteorubra (Goeze) & 131 & 33 & 61 & Ap \\
\hline Total & 2291 & 968 & 798 & - \\
\hline$\%$ & 56,47 & 23,86 & 19,67 & - \\
\hline $\mathrm{N}$ species & 32 & 31 & 29 & - \\
\hline
\end{tabular}

$\mathrm{Mi}=$ predators of mites, $\mathrm{Ap}=$ Aphidophagous, $\mathrm{Co}=$ predators of coccids, $\mathrm{My}=$ Mycophagous, $\mathrm{Al}=$ Predators of aleyrodids, $\mathrm{O}=$ others, Tr.guild $=$ Trophic guild. * shows the species obtained only in 2012 
Table Appendix 2-2013 - Ladybird species collected in vineyards studied and their feeding

\begin{tabular}{|c|c|c|c|c|}
\hline Tribe Chilocorini & Md & $\mathrm{O}$ & $\mathrm{C}$ & Tr. guild \\
\hline Chilocorus bipustulatus (Linnaeus) & 23 & 4 & 2 & $\mathrm{Co}$ \\
\hline \multicolumn{5}{|l|}{ Tribe Coccidulini } \\
\hline Stethorus gilvifrons (Mulsant) & 3 & 2 & 3 & $\mathrm{Mi}$ \\
\hline Stethorus pusillus (Herbst) & 6 & 2 & 4 & $\mathrm{Mi}$ \\
\hline Scymnus (Mimopullus) flagellisiphonatus (Fursch) & 24 & 9 & 6 & Co \\
\hline Scymnus (Neopullus) haemorrhoidalis Herbst & 53 & - & 3 & Ap \\
\hline Scymnus (Neopullus) limbatus Stephens & - & - & 1 & $\mathrm{O}$ \\
\hline Scymnus (Pullus) auritus Thunberg & 4 & 14 & 2 & Ap \\
\hline Scymnus (Pullus) subvillosus (Goeze) & 3 & 5 & 3 & Ap \\
\hline Scymnus (Pullus) suturalis Thunberg & - & - & 1 & $\mathrm{O}$ \\
\hline Scymnus (Scymnus) apetzi Mulsant & 5 & 10 & 3 & Ap \\
\hline Scymnus (Scymnus) apetzoides Capra e Fursch & - & 1 & - & Ap \\
\hline Scymnus (Scymnus) femoralis (Gyllenhal) & 8 & 3 & - & Ap \\
\hline Scymnus (Scymnus) frontalis (Fabricius) & 109 & 52 & 9 & Ap \\
\hline Scymnus (Scymnus) interruptus (Goeze) & 134 & 2 & 2 & Ap \\
\hline Scymnus (Scymnus) rubromaculatus (Goeze) & 2 & 4 & - & Ap \\
\hline Scymnus (Scymnus) rufipes (Fabricius) & 6 & - & 3 & Ap \\
\hline Nephus (Bipunctatus) bipunctatus (Kugelann) & - & - & 1 & Co \\
\hline Nephus (Bipunctatus) bisignatus (Boheman) & 30 & 6 & 4 & Co \\
\hline Clitostethus arcuatus (Rossi) & 1 & 1 & - & $\mathrm{Al}$ \\
\hline Rhyzobius lophanthae (Blaisdell) & 2 & 2 & - & Co \\
\hline \multicolumn{5}{|l|}{ Tribe Coccinellini } \\
\hline Anisosticta novemdecimpunctata (Linnaeus) $* *$ & - & - & 1 & Ap \\
\hline Hippodamia (Hippodamia) variegata Goeze & 12 & 4 & 45 & Ap \\
\hline Tytthaspis sedecimpunctata (Linnaeus) & 1 & 22 & - & My \\
\hline Coccinella (Coccinella) septempunctata Linnaeus & 3 & 10 & 3 & Ap \\
\hline Coccinula quatuordecimpustulata (Linnaeus) & 2 & 8 & 2 & Ap \\
\hline Oenopia conglobata (Linnaeus) & 1 & 3 & - & Ap \\
\hline Oenopia lyncea (Olivier) $* *$ & 1 & - & - & Ap \\
\hline Harmonia axyridis Pallas & 2 & 4 & 1 & Ap \\
\hline Propylea quatuordecimpunctata (Linnaeus) & 44 & 18 & 18 & Ap \\
\hline Psyllobora vigintiduopunctata (Linnaeus) & 15 & 7 & 6 & My \\
\hline \multicolumn{5}{|l|}{ Tribe Diomini } \\
\hline Diomus rubidus (Motschulsky) & 1 & 1 & - & Co \\
\hline \multicolumn{5}{|l|}{ Tribe Platynaspini } \\
\hline Platynaspis luteorubra (Goeze) & 25 & 19 & 10 & Ap \\
\hline Total & 520 & 213 & 133 & - \\
\hline$\%$ & 60,05 & 24,59 & 15,36 & - \\
\hline $\mathrm{N}$ species & 27 & 25 & 23 & - \\
\hline
\end{tabular}

$\mathrm{Mi}=$ predators of mites, $\mathrm{Ap}=$ Aphidophagous, $\mathrm{Co}=$ predators of coccids, $\mathrm{My}=$ Mycophagous, $\mathrm{Al}=$ Predators of aleyrodids, $\mathrm{O}=$ others, $\mathrm{Tr}$. Guilds $=$ Trophic guilds. ${ }^{* *}$ shows the species obtained only in the 2013 